\title{
Understanding The Delivery of Islamophobic Hate Speech Via Social Media In Indonesia
}

Kastolani

IAIN Salatiga, Indonesia

E-mail: kastolani@iainsalatiga.ac.id

DOI: 10.18326/ijims.v10i2.247-270

\begin{abstract}
Various pevious studies on Islamophobia have largely utilized Western perspectives. This occurrs owing to Islam and Muslims being a minority group that is considered a threat to the majority. This article discusses the delivery of Islamophobic hate speech via social media in the context of Indonesia, where the majority of the population are Muslims. The study found that Islamophobia on social media may be understood as a reaction against speeches by Islamic religious figures discrediting Christianity. Such Islamophobic articulation is considered a freedom of opinion, which is constructed on the ground of religion-based political polarization. Subsequently, this study brings into the literature a new understanding of Islamophobia within the context of Muslims as the majority and of netizens' activities on social media in Indonesia. The research data were obtained by observing Facebook, Instagram, YouTube, and Twitter timelines containing Islamophobic hate speech that went viral on social media.
\end{abstract}

Berbagai penelitian sebelumnya tentang Islamophobia sebagian besar telah memanfaatkan perspektif Barat. Artikel ini mendiskusikan penyampaian ujaran kebencian Islamophobia melalui media sosial dalam konteks Indonesia sebagai 
negara yang mayoritas penduduknya penganut agama Islam (muslim). Penelitian ini menemukan bahwa Islamophobia di media sosial dapat dipahami sebagai reaksi terhadap ceramah dari pemuka agama Islam yang mendeskriditkan Kristen. Penyampaian Islamophobia tersebut dianggap sebagai kebebasan berpendapat yang dibentuk berdasarkan polarisasi politik berbasis agama. Sehingga, penelitian ini berkontribusi terhadap pemahaman baru tentang Islamophobia dalam konteks muslim sebagai mayoritas dan aktivitas netizen di media sosial di Indonesia. Data penelitian diperoleh dari pengamatan terhadap media social seperti Facebook, Instagram, YouTube dan Twitter yang memuat ujaran kebencian tentang Islamophobia yang viral di media social.

Keywords: Hate speech; islamophobia; social media; freedom of expression; identity politics

\section{Introduction}

The phenomenon known as Islamophobia appeared in the Western society and political tradition as a form of dominant presupposition regarding Islam. ${ }^{1}$ Islamophobia subsequently expanded as an early symptom of hatred against Islam in the West. ${ }^{2}$ The $9 / 11$ incident is often referred to as a trigger in the rise of Islamophobia in the West. ${ }^{3}$ The incident has induced fear of global terrorist movements perpetrated by a number of people of Muslim faith. Nevertheless, prior to the 9/11 incident, various negative presuppositions against Islam had already emerged.

Meanwhile, in Indonesia, Islamophobia, in its most extreme definition as hatred against Islam, did not initially emerge as a disturbing phenomenon. However, various literatures explain that since the Bali

${ }^{1}$ Scott Poynting and Linda Briskman, "Islamophobia in Australia: From Far-Right Deplorables to Respectable Liberals”, Social Sciences, Volume 7, Number 11 (2018), 1-17.

${ }^{2}$ Marc Hebling, Islamophobia in the West; Measuring and Explaining Individual Attitudes, London: Routledge, 2014.

${ }^{3}$ Carmen Aguilera Carnerero and Abdul Halik Azeez, "Islamonausea, not Islamophobia: The Many Faces of Cyber Hate Speech”, Journal of Arab $\mathcal{E}$ Muslim Media Research, Volume 9, Number 1 (2016), 21-40. 
bombing incident in 2002, Islamophobic symptoms have started to emerge throughout Indonesia. ${ }^{4}$ The emerging phenomenon of Islamophobia may be recognized as fear toward a group of Muslims who have an erroneous understanding of Islam. Even so, the existing Islamophobic phenomenon has yet to reach the most extreme act of Islamophobia, which is the act of hating and insulting Islam as a religion.

Islamophobia in Indonesia has been on the rise as of late in various activities through numerous social media channels such as Facebook, Instagram, YouTube, and Twitter. The Islamophobic phenomenon in the activities of netizens via the various social media platforms have become highly unsettling as it is beginning to head toward the most extreme form of Islamophobia, hating and insulting the religion of Islam.

Social media has subsequently evolved into a means for spreading Islamophobia in Indonesia. ${ }^{5}$ Therefore, given that Indonesia is a country with the largest Muslim population in the world, the presence of social media serves as a very specific context for the expansion of Islamophobia. The proliferation of Islamophobia on social media is also witnessed in America, ${ }^{6}$ Eropa, ${ }^{7}$ and Australia. ${ }^{8}$

The propagation of Islamophobia through social media may have been

${ }^{4}$ P. Ari Subagyo, "Representasi Frame dalam Latar Belakang Wacana Tajuk tentang Terorisme”, Litera, Volume 15, Number 1 (2016), 173-188.

${ }^{5}$ Khoirul Amin, Mohamad Dziqie Aulia Alfarauqi, and Khusnul Khatimah, "Social Media, Cyber Hate and Racism", Komuniti: Jurnal Komunikasi dan Teknologi Informasi, Volume 10, Number 1 (2018), 3-10.

${ }^{6}$ Khaled A. Beydoun, American Islamophobia: Understanding the Roots and Rise of Fear, Oakland, CA: University of California Press, 2018.

${ }^{7}$ Fabio Perocco, "Anti-Migrant Islamophobia in Europe: Social Roots, Mechanisms and Actors", REMHU: Revista Interdisciplinar da Mobilidade Humana, Volume 26, Number 53 (2018), 25-40. See olso: Engy Abdelkader,"A Comparative Analysis of European Islamophobia: France, UK, Germany, Netherlands and Sweden”, UCLA Journal of Islamic and Near Eastern Law, Volume 16, Number 1 (2017), 29-63.

${ }^{8}$ Rachel Woodlock, "Identity and Islamophobia: An Australian Investigation”, in Douglas Pratt and Rachel Woodlock (ed), Fear of Muslims? International Perspectives on Islamophobia, Switzerland: Springer, 2016: 131-151. 
brought about by the advent of communication technology inducing changes in the pattern of every individual's consumption and distribution of information. As a result, social media themselves are becoming difficult to articulate. It may be identified through the features its channels maintain so that the direction of the messages may be identified. ${ }^{9}$ Social media may also refer to a specific application as its platform in order to demonstrate the differences in its model of interaction. ${ }^{10}$ Additionally, through social media a netizen is afforded free reign to convey expressions of hatred with Islam-hating contents due to differences in their utilization of the social media. This includes the impacts generated by individuals with social support behind them and those without any social support whatsoever from the surrounding environment. This means that Islamophobic contents are disseminated via social media by the perpetrators because they feel there is no control from the surrounding environment. ${ }^{11}$

Thus, there are three interrelated elements discussed in this article. First, about Islamophobia in numerous concepts such as fear, stereotype, prejudice, and racism; second, about the activities of Indonesian netizens on social media with Islamophobic contents; and third, the specific context that covers Islamophobia and the activities of Indonesian netizens on social media. By referring to these three elements, this article has made the following problem statement: How can we understand Islamophobic hate speech delivered via social media in Indonesia?

In the context of Indonesia today, there is a relevant need to study Islamophobia on social media. Aside from the lack of research on

${ }^{9}$ Michael L. Kent, "Directions in Social Media for Professional and Scholars", in R.L. Heath (ed), Handbook of Public Realitions, Thousand Oaks: Sage, 2010: 643-656.

${ }^{10}$ Philip N. Howard and Malcolm. R. Parks, "Social Media and Political Change: Capacity, Constraint, and Consequence”, Journal of Communication, Volume 62, Number 2 (2012): 359-362.

${ }^{11}$ Kiesler Bessiere, et al., "Effects of Internet Use and Social Resources on Changes in Depression, Information, Communication Society”, Information, Communication $\mathcal{E}$ Society, Volume 11, Number 1 (2008), 47-70. 
Islamophobia on social media, Indonesia is currently a democratic country with a Muslim majority and as such, the state guarantees to provide freedom of expression for its citizens. As a country with a population of Muslim majority, Islamophobia is also a threat to Islam's peaceful countenance.

\section{The rise of Islamophobia}

Islamophobia is a term that is formed by combining two words, Islam and phobia, which can simply be defined as fear of Islam. Historically speaking, fear of Islam has developed in Europe since the 7 th century. ${ }^{12}$ Since Islam emerged in Arabia, the fear of Islam has frequently been referred to as the "orientalist's" vision of the Arab world. ${ }^{13}$ Meanwhile, Ogan, Christine; Lars; Pennington, \& Manaf noted that fear of Islam emerged within most of the Christian population in Europe since immigrants from Muslim countries began arriving to Europe in the early period of the 14th century. ${ }^{14}$

Islamophobia is, thus, a concept that emerged within the context of changing and dynamic cultural, political, and social relations. This is why Galiie has long since mentioned that Islamophobia as a concept is basically contested by numerous disciplines of science. ${ }^{15}$ As a result, Islamophobia is attributed many definitions and explanations based on the field of science/knowledge making use of it, without any mutual consensus on how it should actually be defined.

Moosavi considers Islamophobia as a form of stereotyping against Muslims because it is a product brought about by the meeting of two

\footnotetext{
${ }^{12}$ Giulia Evolvi, "Hate in a Tweet: Exploring Internet-Based Islamophobic Discourses", Religions, Volume 9, Number 10 (2018), 1-14.

13Edward W. Said, Orientalism, London: Penguin, 2003.

${ }^{14}$ Christine Ogan, Lars Willnat, Rosemary Pennington and Manaf Bashir, "The Rise of antiMuslim prejudice: Media and Islamophobia in Europe and the United States", International Communication Gazette, Volume 76, Number 1 (2014), 27-46.

${ }^{15}$ Walter B, Gallie, "Essentially Contested Concepts", Proceedings of the Aristotelian Society, Volume 56 (1995), 167-198.
} 
or more differing cultures. ${ }^{16}$ Meanwhile, Kunst, Sam, and Ulleberg see Islamophobia as a form of fear of Islam or the Muslim community. ${ }^{17}$ Imhoff and Recker, on the other hand, construe Islamophobia as a form of prejudice with a negative tendency against Muslims. ${ }^{18}$ Meer and Modood describe Islamophobia as one of the forms of racism based on religious differences. ${ }^{19}$ A broader understanding that accommodates the various definitions above is proposed by Bleich, ${ }^{20}$ who defines Islamophobia as "indiscriminative negative attitudes or emotions directed at Islam or Muslims," including “aversion, jealousy, suspicion, disdain, anxiety, rejection, contempt, fear, disgust, anger, and hostility". ${ }^{21}$

The elaboration Bleich provides on Islamophobia, which is quite extensive, indicates that the concept of Islamophobia exists within a time and space that is different, dynamic, and ever-changing on account of the various religious, cultural, political and social relations that ensue. Consequently, in practice, the concept of Islamophobia also appears in a variety of differing forms. However, forms of Islamophobic behaviors can be identified as explicit and implicit Islamophobia. ${ }^{22}$

\footnotetext{
${ }^{16}$ Leon Moosavi, "The Racialization of Muslim Converts in Britain and Their Experiences of Islamophobia”, Critical Sociology, Volume 41, Number 1 (2015), 41-56.

${ }^{17}$ Jonas R. Kunst, David L. Sam and Pal Ulleberg, "Perceived Islamophobia: Scale Development and Validation”, International Journal of Intercultural Relations, Volume. 37, Number 2 (2013), 225-237.

${ }^{18}$ Roland Imhoff and Julia Recker, "Differentiating Islamophobia: Introducing a New Scale to Measure Islamoprejudice and Secular Islam Critique", Political Psychology, Volume 33, Number 6 (2012), 811-824.

${ }^{19}$ Nasar Meer and Tariq Modood, "Patterns of Prejudice Refutations of Racism in the Muslim Question”, Patterns of Prejudice, Volume 43, Number 3-4 (2009), 335-354.

${ }^{20}$ Erik Bleich, "What is Islamophobia and How Much is There? Theorizing and Measuring an Emerging Comparative Concept", American Behavioral Scientist, Volume 55, Number 12 (2011), 1581-1600.

${ }^{21}$ Erik Bleich, "Defining and Researching Islamophobia", Review of Middle East Studies, Volume 46, Number 2 (2012),180-189.

${ }^{22}$ Kevin L. Nadal, et al., "Subtle and Overt Forms of Islamophobia: Microaggressions toward Muslim Americans”, Journal of Muslim Mental Health, Volume 6, Number 2 (2012), 16-37; Thomas F. Pettigrew and Roel W. Meertens, "Subtle and blatant prejudice in Western
} 
A different explanation on Islamophobia is presented by Runnymede Trust. Islamophobia is defined as "unfounded hostility toward Islam." 23 This definition places the Muslim community and individuals outside of political and social affairs as its main underlying context. It raised differences between the concept of Islamophobia and legitimate criticism toward Islam and Muslims.

These differences subsequently led to open and closed perspectives on Islam and Muslims. The open perspective is a form of constructive criticism of the various practices of Islamic belief. The criticisms would then generate constructive debates within a democratic society. This perspective sees Islamophobia as a form of fear of Islam due to the lack of knowledge about Islam.

As for the closed perspective, it is based on negative prejudice and hostility toward Islam and the Muslim community. According to Runnymede Trust, such closed perspective underlies the emergence of Islamophobia. Closed perspective emerges in 8 forms: monolithic, sparate, inferior, enemy, manipulative, criticism of the West rejected offhandedly, discriminatory, Islamophobia is viewed as natural. ${ }^{24}$

The eight categories from the closed perspectives of Islam and Muslims serve as the basis for Islamophobia to emerge. These various closed views do not allow any room for discussion and debate about Islam and Muslims as observed in the open views. According to Runnymede Trust, each of the perspectives may emerge on its own as a form of Islamophobia or they may come together and mutually stimulate one another. ${ }^{25}$ The process

Europe", European Journal of Social Psychology, Volume 25, Number 1 (1995), 57-75.

${ }^{23}$ Runnymede Trust, Islamophobia: A Challenge for Us All, 1997, Retrieved on April 23, 2019 at: https://www.runnymedetrust.org/companies/17/74/Islamophobia-A-Challengefor-Us-All.html.

${ }^{24}$ Runnymede Trust, Islamophobia...

${ }^{25}$ Runnymede Trust, Islamophobia... 
may exacerbate Islamophobia, making it more expansive and more quickly disseminated. This is why Islamophobia is such a daunting concept to define.

The understanding about and development of Islamophobia is by no means separable from the dynamics of global politics. Islamophobia has explicitly emerged since the 9/11 incident in 2001 in America, which is closely related to the global war against terrorism, instilling a negative impact on the public's perception of Islam. ${ }^{26}$ Cainkar found that following the 9/11 event, Muslims across America experienced hatred, with women experiencing twice as much hatred. ${ }^{27}$ Ultimately, the 9/11 event has resulted in an anti-Muslim attitude in numerous countries. ${ }^{28} \mathrm{~A}$ similar atmosphere was observed in Indonesia following the 1st Bali bombing in 2002 and the 2nd Bali bombing in 2005, the Australian Embassy bombing in Jakarta in 2004, and the JW Marriot hotel and Ritz Carlton hotel bombings in Jakarta in 2009. 29

The situation has become increasingly difficult as the mass media also presented negative views of Islam. ${ }^{30}$ Subsequently, according to Stack (2017), Islamophobia has recently achieved new height during the 2016 US presidential election, which was won by Donald Trump. Seven days after the election, the Trump administration issued a travel ban to seven majority-Muslim countries. ${ }^{31}$ As a result, Islam's negative image has

\footnotetext{
${ }^{26}$ Naved Bakali, Islamophobia: Understanding Anti-Muslim Racism Through the Lived Experiences of Muslim Youth, Rotterdam, The Netherlands: Sense Publishers, 2016.

${ }^{27}$ A. Louise Cainkar, Homeland Insecurity: The Arab American and Muslim American experience after 9/11, New York: Russsel Sage Foundation, 2011.

${ }^{28}$ Steve Garner and Saher Selod, "The Racialization of Muslims: Empirical Studies of Islamophobia”, Critical Sociology, Volulme 41, Number 1 (2015), 9-19.

${ }^{29}$ Moordiningsih, Islamophobia dan Strategi Mengatasinya, Yogyakarta: Universitas Gadjah Mada, 2004.

${ }^{30}$ Elizabeth Poole and John E. Richardson, Muslims and the News Media, London: I.B.Tauris, 2014.

${ }^{31}$ Liam Stack, "Trump's Executive Order on Immigration: What We Know and What We Don't”, Retrieved on September 29, 2018 from https://www.nytimes.com/2017/01/29/us/
} 
only become more pronounced. According to the Pew Research Center, Americans considered Muslims as the most negative in comparison to other religious groups. ${ }^{32}$ This explains that Islamophobia has social and political contexts. ${ }^{33}$

\section{The emergence of Islamophobia: the context of social media}

In the Indonesian context, several Islamophobic contents were also distributed via social media. This is made even more possible and unrestricted since social media activities may be conducted by disguising the identity of the user through the use of anonymous accounts. Pseudonymous or anonymous accounts are fake account names or aliases used on social media. According to Erjavec and Kovacic, both credible and pseudonymous accounts may promote positive contents, yet it may also be employed to disseminate negative contents such as hate speeches. ${ }^{34}$ These sorts of contents may also provoke other reactive hate comments.

The use of anonymous accounts may weaken or remove control over the distributed Islamophobic contents. ${ }^{35}$ This means that the true identity of a netizen could not be openly known if that individual were using

trump-refugee-ban-muslim-executive-order.html

${ }^{32}$ Pew Research Center, "U.S. Muslims Concerned About Their Place in Society, but Continue to Believe in the American Dream, " Pew Research Center. Religion and Public Life, 2017. Retrieved on April 23, 2019 at: https://www.pewresearch.org/wp-content/uploads/ sites/7/2017/07/U.S.-MUSLIMS-FULL-REPORT.pdf

${ }^{33}$ Khaled A Beydoun, American Islamophobia .....

${ }^{34}$ Karmen Erjavec and Melita Poler Kovacic, "You Don't Understand, This is a New War: Analysis of Hate Speech in News Web Sites' Comments”, Mass Communication and Society, Volume 15, Number 6 (2012), 899-920.

${ }^{35} \mathrm{John}$ A. Bargh and Katelyn Y.A. McKenna, "The Internet and Social Life", Annual Review of Psychology, Volume 55 (2004), 573-590; Julie Blair, "New Breed of Bullies Torment Their Peers on the Internet", Education Week, Volume 22, Number 21 (2003), 6-7; Danielle Keats Citron, Hate Crimes in Cyberspace, Cambridge: Harvard University Press, 2016; Ernest VE. Hodges and David G. Perry, "Personal and Interpersonal Antecedents and Consequences of Victimization by Peers”, Journal of Personality Social Psychology, Volume 76, Number 4 (1999), 677-685. 
anonymous accounts in their social media activities. This results in an unrestricted freedom to produce Islamophobic contents. Hence, every netizen intending to produce Islamophobic contents via social media does not see the need to control what they want to express. Consequently, the process of echo chambers being created on social media becomes a lot faster. Netizens reading the contents can be more easily upset when reading Islamophobic contents rather than choosing to investigate who owns the social media account. For that reason, internet-based social media does provide significant opportunities as a space to disseminate cyber hatred. ${ }^{36}$

This study found that four of the most popular social media platforms, which are Facebook, Instagram, YouTube, and Twitter, have been used to spread Islamophobic contents in Indonesia. The four major social media platforms were determined by referring to survey results obtained by APJII (2019) concerning the behavior of internet users in Indonesia. The survey report states that as many as $50.7 \%$ of netizens visit Facebook in their activities on social media. This is then followed by Instagram with $17.8 \%$, YouTube $15 \%$, and Twitter $1.7 \% .^{37}$
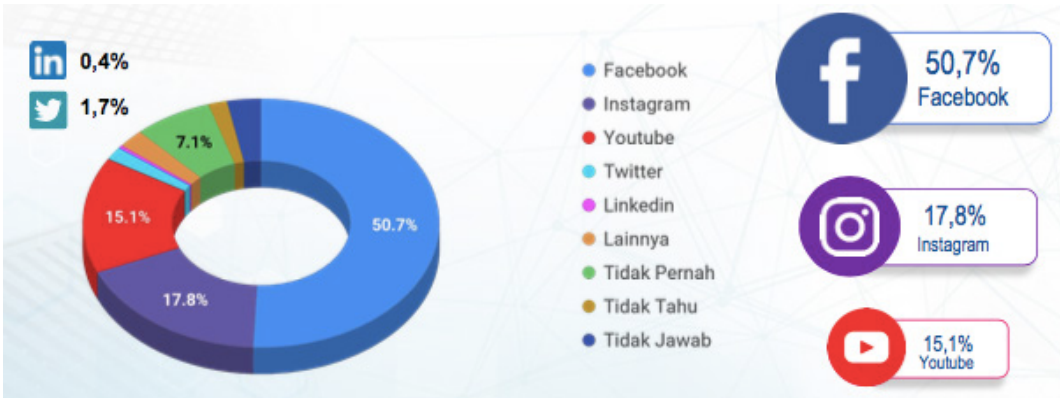

${ }^{36}$ Karuppannan Jaishankar, "Cyber Hate: Antisocial Networking in the Internet", International Journal of Cyber Criminology, Volume 2, Number 2 (2008), 16-20.

${ }^{37}$ Assosiasi Penyelenggara Jasa Internet Indonesia (APJII), "Laporan Survei Penetrasi \& Profil Perilaku Pengguna Internet Indonesia ”, Retrieved on February 23, 2019 from https:// www.apjii.or.id/content/read/39/410/Hasil-Survei-Penetrasi-dan-Perilaku-Pengguna-InternetIndonesia-2018 
Islamophobic contents on the four social media platforms may be categorized as strong Islamophobia. According to Vidgen and Yasseri, strong Islamophobia is defined as "speech which explicitly expresses negativity against all Muslims". ${ }^{38}$ Some examples of strong Islamophobic contents found on the four social media platforms, among others, are:

Table 1: Examples of strong Islamophobic hate speech content on social media, namely Facebook, Instagram, YouTube, and Twitter.

\begin{tabular}{|c|c|c|}
\hline $\begin{array}{l}\text { Social } \\
\text { Media } \\
\text { Platform }\end{array}$ & Islamophobic Contents & $\begin{array}{l}\text { Social Media } \\
\text { Account Sources }\end{array}$ \\
\hline \multirow[t]{2}{*}{ Facebook } & $\begin{array}{l}\text { "Islam itu agama binatang" (Islam is a } \\
\text { beast religion). }\end{array}$ & Gious Nainggolan \\
\hline & $\begin{array}{l}\text { "Ini namanya orang Islam gila. Kontol } \\
\text { sama kalian, jancok" (These Muslims are } \\
\text { crazy. Fuck you, you dicks). }\end{array}$ & Candra Krismon \\
\hline Instagram & $\begin{array}{l}\text { "Kenapa rupanya kalo bendera tauhid } \\
\text { dibakar? Tuhan kalian ikutterbakar } \\
\text { rupanya? Makanya,jangan banyak kali } \\
\text { ikut pengajianyang ngajarkan budaya, jadi } \\
\text { tololbangsad Tuhan kalian aja antengdiatas } \\
\text { lagi gitaran sambil mabukamer dan nulis } \\
\text { puisi bokep, klenpulak yang sibuk" (What's } \\
\text { wrong with burning the tauhid flag? Is } \\
\text { your God burned along with it? That's } \\
\text { why, don't attend Muslim forums that } \\
\text { teach culture, you become stupid, you } \\
\text { sons of bitches. Instead, your God } \\
\text { remains calm up there playing the guitar, } \\
\text { drunk on red wine and writing porn } \\
\text { poetry, while you all get worked up). }\end{array}$ & Rezahardiansyah7071 \\
\hline
\end{tabular}

\footnotetext{
${ }^{38}$ Bertie Vidgen and Taha Yasseri, "Detecting Weak and Strong Islamophobic Hate Speech
} on Social Media", retrieved on September 27, 2018 at https://arxiv.org/abs/1812.10400 


\begin{tabular}{|c|c|c|}
\hline $\begin{array}{c}\text { Social } \\
\text { Media } \\
\text { Platform }\end{array}$ & Islamophobic Contents & $\begin{array}{c}\text { Social Media } \\
\text { Account Sources }\end{array}$ \\
\hline YouTube & $\begin{array}{l}\text { "Islam adalah ajaran sesat. Yang disembah } \\
\text { itu apa? Nabi Muhammad itu siapa? } \\
\text { Kan sama seperti manusia juga" (Islam } \\
\text { is a heretical teaching. What is being } \\
\text { worshipped? Who is the Prophet } \\
\text { Muhammad? Isn't he the same, a } \\
\text { human as well) }\end{array}$ & Jesicoplax \\
\hline Twitter & $\begin{array}{l}\text { "Setelah Nabi } \mathcal{E} \text { Tuhan GADUNGAN } \\
\text { dipahami masyarakat luas, yang masih } \\
\text { JUAL ayat Allah SWT Eु Hadis } \\
\text { Muhammad, adalah PENIPU" (Once } \\
\text { the FAKE God \& Prophet are known } \\
\text { by the wider public, those who still } \\
\text { PROMOTE the verses of Allah SWT \& } \\
\text { the hadith of Muhammad are LIARS). } \\
\text { "Islam berdiri di atas dasar yang PASTI } \\
\text { SALAH, lihat hasilnya, mulai dari } \\
\text { Muslim yang tak produktif sampai } \\
\text { TERORIS Islam" (Islam stands above } \\
\text { a DEFINITELY ERRONEOUS basis, } \\
\text { look at the results, from unproductive } \\
\text { Muslims to Islamic TERRORISTS). }\end{array}$ & @hikdun \\
\hline
\end{tabular}

In general, the various existing social media have the following features: textual (hyper textual), interactional (hyper interactional), transactional, virtual, fake, mediation, and ostentatious. ${ }^{39}$ Given those social media attributes, Islamophobic contents on the four social media platforms that people use may be reproduced and redistributed across channels among the other social media platforms. Such a social media feature is considered

\footnotetext{
${ }^{39}$ Martin Lister, et al., New Media: a Critical Introduction, London: Routledge, 2010.
} 
by Wood and Smith to be a prosumer (producer and consumer). ${ }^{40}$

In terms of sentence and word choices used in the contents of various religious hate speeches, they are described by Pohjonen and Udupa as extreme speech, ${ }^{41}$ whereas in terms of social media as a communication channel utilized to distribute Islamophobic contents, social media may be construed as a powerful tool for spreading Islamophobia. Having such power, social media may play an extremely crucial role in managing activities on social media and its relations with Muslim identity or Islamophobia. ${ }^{42}$

\section{Islamophobia as a reaction, expression, and identity politics}

Referring to the aforementioned Table 1, this study found a new category in the format of Islamophobic contents delivered via social media. The Islamophobia that emerged in the various speeches found on social media is a form of hatred toward Islam as a belief or teaching. This category of Islamophobia is unlike the two categories of Islamophobia presented by Vidgen and Yasseri (2018), who categorize Islamophobia into explicit and implicit Islamophobias, while Bleich (2012) categorizes Islamophobia into strong and weak. Both of them define the concept of Islamophobia by referring to Muslims as followers of Islam, be it as individuals, as a group, or a Muslim community.

\footnotetext{
${ }^{40}$ Andrew F. Wood and Matthew J. Smith, Online Communication: Linking, Technology, Identity, and Culture, New York and London: Routledge, 2017.

${ }^{41}$ Matti Pohjonen and Sahana Udupa, "Extreme Speech Online: A Anthropological Critique of Hate Speech Debates", International Journal of Communication, Volume 11 (2017), $1173-1191$.

${ }^{42}$ Rusi Jaspal and Marco Cinnirella, "Media Representations of British Muslims and Hybridised Threats to Identity", Contemporary Islam, Volume 4, Number 3 (2010), 289-310; Nabil Echchaibi, "Muslimah Media Watch: Media Activism and Muslim Choreographies of Social Change", Journalism, Volume 14, Number 7 (2013), 852-867; Aparna Hebbani and Charise-Rose Wills, "How Muslim Women in Australia Navigate through Media (Mis) Representations of Hijab/Burqa", Australian Journal of Communication, Volume 39, Number 1 (2012): 87-100; Anne Aly, "Fear Online: Seeking Sanctuary in Online Forums", in Anna Hayes and Robert Mason (ed), Cultures in Refuge: Seeking Sanctuary in Modern Australia, Farnham : Ashgate, 2012: 163-178.
} 
Meanwhile, this study found that Islamophobic contents were directed at the belief and teachings of Islam, not at Muslims as followers of Islam. The idea is interesting given that this happened in Indonesia where the majority of its population are Muslims, which explains that Islamophobia has numerous aspects that are interrelated or associated with various new elements that have not been revealed.

This study found that it is the opposite of that, where Islamophobic hate speeches are directed at Islamic belief or teachings. Based on this argument, we affirm that hatred against Islamic teachings or belief that is delivered openly through various social media platforms may emerge because of the following reasons:

First, it is a reaction to religious sermons conveyed by Muslim clerics who discredit other religions, especially Christianity. This refers to a discussion on how Islamophobic contents delivered via social media directed at Islamic teachings and belief are considered as a reaction to sermons presented by Islamic group(s) that are often identified as radical or fundamental Islamic group(s), such as FPI (Islamic Defenders Front).

In one of his speeches, the Grand Imam of FPI, Habib Rizieq Shihab stated the following, "He even said, Habib Rizieq, Merry Christmas. What does it mean? Happy birthday Jesus Christ the son of God. I responded, 'Lam yalid walam yulad', He neither begat nor was begotten. If God gave birth, who would be the midwife? "This speech was uploaded by a netizen under the account name of Zetro Media onto the social media YouTube. ${ }^{43}$ The video of that speech subsequently went viral on social media as it contains hate speech directed toward the Christian faith. Such religious sermon may become a trigger for Islamophobia directed at the sacred teachings and belief of Islam to emerge.

${ }^{43}$ Zetro Media, Habib Rizieq, "Kalau Tuhan beranak bidannya siapa?", Retrieved on December 29, 2018 from ://www.youtube.com/watch?v=H7LdbSDPRg4 
Second, it is a form of freedom of expression for netizens in Indonesia's democratic climate. This refers to a discussion on how Islamophobic contents delivered via social media directed at Islamic belief or teachings are considered to be a form of freedom of expression. These are two things that have long become a dilemma for countries that adhere to democracy. ${ }^{44}$ On the one hand, the state must guarantee freedom of expression for its citizens and, on the other hand, there are certain issues (like religion) that must be protected from various forms of insult.

Given the argument that religious followers as citizens have the rights to protect their religion as something sacred, freedom of expression that leads to insulting religious teachings or belief should be restricted. Protecting one's religion is even suggested in the teaching of Islam (see the Qur'an, As-Saff: 14).

In the Indonesian context, Islamophobic contents delivered via social media directed at Islamic teachings and belief contain imminent danger that threatens social order. Some Muslim community groups have in fact been reported by a number of mass media to have sought, found, and reported to the police netizens who produced and distributed Islamophobia in their various social media accounts. ${ }^{45}$ According to Fauzi, Bagir and Rafsadi, insult directed toward religion (Islam) in Indonesia has indeed caught the attention of Indonesian Muslims as the majority. ${ }^{46}$

Third, it is a form of identity politics maintained by netizens on social media, which is the result of religion-based political polarization. This refers

\footnotetext{
${ }^{44}$ Toni M. Massaro, "Equality and Freedom of Expression: A Hate Speech Dilemma", William Ë Mary Law Review, Volume 32, Number 2 (1991), 211-265.

${ }^{45}$ Nafiysul Qodar, "Polisi tangkap pemilik akun @reza_hardiansyah_7071 yang hina Islam”, 2018, Merdeka.com. Retrieved on February 23, 2019 from https://www.merdeka.com/ peristiwa/polisi-tangkap-pemilik-akun-rezahardiansyah7071-yang-hina-islam.html

${ }^{46}$ Ihsan Ali Fauzi, Zainal Abidin Bagir and Irsyad Rafsadi, Kebebasan, Toleransi Dan Terorisme; Riset Dan Kebijakan Agama Di Indonesia, Jakarta: Pusat Studi Agama dan Demokrasi Yayasan Paramadina, 2017.
} 
to a discussion on how Islamophobic contents delivered via social media are considered an expressive form of hate politics emerging from religious identity. According to Syahputra (2017), the polarization is formed in three stages within a climate of liberal virtual democracy (social media). The liberalization of virtual democrazy has propelled social media awareness to become a power of change, established a polarization of netizens between the conservative group (Islam) and the liberal group (nationalist), and has sociologically motivated mass protests to happen, which were conducted repeatedly with exceedingly large number of multitudes. ${ }^{47}$

The discussion in this section can begin from the rise of the Islamism and Salafism movements as a form of Islamic conservatism movement in Indonesia. According to Wildan, the effect of Islamism and Salafism ideology has spread far and wide throughout Indonesia, which was initially recognized as having a tolerant and polite Islamic countenance. ${ }^{48}$ One of the prominent elements in Islamism and Salafism is the political movement to implement and uphold Islamic law. The proposal to implement Islamic law allegedly originated from a radical Islam group. ${ }^{49}$ According to Bruinessen (2002), the radical Islam group constantly employ jihad as a discourse to mobilize their followers. ${ }^{50}$

The Islamism and Salafism movement recently emerged and reconsolidated as it was triggered by the Defend Islam Rallies, which were

\footnotetext{
${ }^{47}$ Iswandi Syahputra, "Demokrasi Virtual dan Perang Siber di Media Sosial: Perspektif Netizen Indonesia”, Jurnal ASPIKOM, Volume 3, Number 3 (2017), 457-475.

${ }^{48}$ Muhammad Wildan, "Aksi Damai 411-212, Kesalehan Populer, dan Identitas Muslim Perkotaan Indonesia", Maarif, Volume 11, Number 2 (2016), 188-202.

${ }^{49}$ Edward Aspinall, "Elections and the Normalization of Politics in Indonesia." South East Asia Research, Volume 13, Number 2 (2005), 117-156; Marcus Mietzner, "Comparing Indonesia's Party Systems of the 1950s and the Post-Soeharto Era: From Centrifugal to Centripetal Inter-Party Competition”, Journal of Southeast Asian Studies, Volume 39, Number 3 (2008), 431-453.

${ }^{50}$ Martin van Bruinessen, "Genealogies of Islamic Radicalism in Post-Suharto Indonesia”, South East Asia Research, Volume 10, Number 2 (2002), 117-154.
} 
held numerous times and attended by millions of people. These mass protests were a reaction to the blasphemy against Islam perpetrated by the then Governor of Jakarta SCR, Basuki Tjahaja Purnama (commonly known as Ahok) in one of his speeches. The Defend Islam Rallies were initiated by FPI and supported by other Islamic groups. ${ }^{51}$ Although the recurrent massive protests were conducted to defend Islam from blasphemy, they were inseparable from the interests of identity politics because these protests were held during the period leading up to the 2017 Jakarta SCR Gubernatorial Election and continued up to the 2019 Presidential Election.

The recurring Defend Islam Rallies were successfully held on account of the growing democratic climate in Indonesia and the power that social media and netizens' activities in them had. ${ }^{52}$ Hence, it is plausible that such democratic context and intensity of social media activities has allowed various ideas, teachings, and expressions to be challenged, tested, or even opposed. ${ }^{53}$ Under such a context, anyone is able to berate one another or spread hatred on social media. According to Suller every netizen may convey things on social media that they would never do in their actual daily life. ${ }^{54}$

To some Muslim residents of Jakarta, the Defend Islam Rallies did not stand alone as merely being triggered by the religious blasphemy

${ }^{51}$ Mark Woodward and Amanah Nurish, "Quo Vadis FPI dalam Aksi Bela Islam",Maarif, Vol. 11, No. 2 (2016): 105-122; Ahmad Najib Burhani, "Aksi Bela Islam: Konservatisme dan Fragmentasi Otoritas Keagamaan”, Maarif, Volume 11, Number 2 (2016),15-29.

${ }^{52}$ Muzayyin Ahyar and Alfitri, "Aksi Bela Islam: Islamic Clicktivism and the New Authority of Religious Propaganda in the Millennial Age in Indonesia”, Indonesian Journal of Islam and Muslim Societies, Volume 9, Number 1 (2019), 1-29; Iswandi Syahputra, "Media Sosial dan Prospek Muslim Kosmopolitan: Konstruksi \& Peran Masyarakat Siber pada Aksi Bela Islam”, Jurnal Komunikasi Islam, Volume 8, Number 1 (2018),19-40.

${ }^{53}$ Daniel Trottier and Christian Fuchs, Social Media, Politics and the State: Protest, Revolutions, Riots, Crime and Policing in the Age of Facebook, Twitter and Youtube, New York: Routledge, 2015.

${ }^{54}$ John Suler, "The Online Disinhibition Effect", Cyberpsychology and Behavior, Vol. 7, No. 3 (2004), 321-325. 
perpetrated by the former Governor of Jakarta SCR, Basuki Tjahaja Purnama (Ahok). The rallies were an accumulation of various political pressures experienced by some of the Muslim communities in Jakarta through Ahok's policies as the Governor of Jakarta SCR. They considered Ahok's policies Governor who is unfair to the Muslim communities in Jakarta. Some of the policies that were deemed detrimental to the Muslim community as the majority and that became controversies, for example, were prohibiting Muslims to hold takbiran (recital of God's greatness) in public around the city to celebrate Eid al-Fitr ${ }^{55}$, prohibiting Muslim residents to slaughter sacrificial animals on school grounds to celebrate Eid al-Adha, ${ }^{56}$ or allowing restaurants to remain open when Muslims were observing their holy month of Ramadan. ${ }^{57}$

The various relations among influences of ideology, politics, power, identity, religious authority, and mass rallies have subsequently become a discourse for netizens on various social media channels. The conversation dynamics within such a context have consequently brought about Islamophobic contents delivered via social media, which is an expressive form of hate politics derived from religious identity. Thus, the emergence of Islamophobic contents disseminated via netizens' activities on social media in the Indonesian context is not only driven by hate, fear, or misperception about Islam or Muslims, but it is also affected by the practice of religionbased identity politics.

${ }^{55}$ Wahyu Sabda Kuncahyo, "Tolak Larangan Ahok, PPP Gelar Takbir Keliling”. Retrieved on February 25, 2019 from http://nusantara.rmol.co/read/2016/07/05/252300/TolakLarangan-Ahok,-PPP-Gelar-Takbir-Keliling-

${ }^{56}$ Yuanita, "Ahok Larang Pemotongan Hewan Kurban di Sekolah". Retrieved on February 24, 2019 from http://metro.sindonews.com/read/1042040/171/ ahok-larang-pemotonganhewan-kurban-di-sekolah-1441692072

${ }^{57}$ Fakhri Fakhrizal, "Ahok Izinkan Rumah Makan Buka Selama Ramadan”. Retrieved on February 23, 2019 from http://news.okezone.com/read/2015/06/17/338/ 1166741/ ahokizinkan-rumah-makan-buka-selama-ramadan 


\section{Conclusion}

The delivery of Islamophobic hate speech via social media in the Indonesian context may be analyzed into three divisions. First, it is a reaction to religious sermons made by Muslim clerics who discredit other religions, particularly Christianity. Second, it is a form of freedom of expression for netizens within Indonesia's democratic climate. Third, it is a form of netizens' identity politics on social media caused by the impact of religion based political polarization.

The context and relation of the three factors above explains that Islamophobia may also happen in countries where the majority of its population are Muslims. The understanding of Islamophobia in this context can, thus, be taken as a new perspective in understanding the dynamics of Islamophobia that has been developing through the Western perspective. Theoretically speaking, the study may have implications on new understanding of interreligious tolerance in the context of new media presence in democratic countries, such as Indonesia. Hence, the study results may practically be utilized by religious followers and figures in their religious activities, particularly on social media.

The research has a methodological limit as it lacks appropriate technological tools to detect Islamophobic contents or the use of robot accounts in spreading Islamophobia on social media. This leads to further questions as to why the spread of Islamophobia on social media uses anonymous or robot accounts. Can this trigger violent interreligious clashes on social media? These issues may be taken up as the focus of future studies by using technological tools that are based on big data. 


\section{Bibliography}

Abdelkader, Engy, "A Comparative Analysis of European Islamophobia: France, UK, Germany, Netherlands, and Sweden”, UCLA Journal of Islamic and Near Eastern Law, Volume 16, Number 1 (2017): 29-63.

Ahyar, Muzayyin and Alfitri, "Aksi Bela Islam: Islamic Clicktivism and the New Authority of Religious Propaganda in the Millennial Age in Indonesia", Indonesian Journal of Islam and Muslim Societies, Volume 9, Number 1 (2019): 1-29.

Aly, Anne, "Fear Online: Seeking Sanctuary in Online Forums", in Anna Hayes and Robert Mason (ed), Cultures in Refuge: Seeking Sanctuary in Modern Australia. Farnham: Ashgate, 2012: 163-178.

Amin, Khoirul., Mohamad Dziqie Aulia Alfarauqi, and Khusnul Khatimah, "Social Media, Cyber Hate, And Racism", Komuniti: Jurnal Komunikasi dan Teknologi Informasi, Volume 10, Number 1 (2018): 3-10.

APJII, Assosiasi Penyelenggara Jasa Internet Indonesia, , "Laporan Survei Penetrasi \& Profil Perilaku Pengguna Internet Indonesia ”, Retrieved on February 23, 2019 from https://www.apjii.or.id/content/read/39/410/Hasil-SurveiPenetrasi-dan-Perilaku-Pengguna-Internet-Indonesia-2018

Aspinall, Edward, "Elections and the Normalization of Politics in Indonesia", South East Asia Research, Volume 13, Number 2 (2005): 117-156.

Bakali, Naved, Islamophobia: Understanding Anti-Muslim Racism Through the Lived Experiences of Muslim Youth. Rotterdam, The Netherlands : Sense Publishers, 2016.

Bargh, John A and McKenna, Katelyn Y.A, "The Internet and Social Life", Annual Review of Psychology, Volume 55 (2004): 573-590.

Bessiere, Kiesler., et. al., "Effects of Internet Use and Social Resources on Changes in Depression, Information, Communication Society", Information, Communication $\mathcal{E}$ Society, Volume 11, Number 1 (2008): 47-70.

Beydoun, Khaled A, American Islamophobia: Understanding the Roots and Rise of Fear. Oakland, CA: University of California Press, 2018.

Blair, Julie, "New Breed of Bullies Torment Their Peers on the Internet"' Education Week, Volume 22, Number 21 (2003): 6-7.

Bleich, Erik, "Defining and Researching Islamophobia", Review of Middle East Studies, Volume 46, Number 2 (2012) :180-189.

Bleich, Erik, "What is Islamophobia and How Much is There? Theorizing and Measuring an Emerging Comparative Concept", American Behavioral Scientist, Volume 55, Number 12 (2011): 1581-1600. 
Boulahnane, Saad, "Ground Zero Mosque in the Context of America's Post-9/11 Religious Pluralism: CDA of Mainstream News Media's Coverage of the Discursive Event", Indonesian Journal of Islam and Muslim Societies, Volume 8, No. 2 (2018): 253-80 https://doi.org/10.18326/ijims.v8i2.253-279

Bruinessen, Martin van, "Genealogies of Islamic Radicalism in Post-Suharto Indonesia." South East Asia Research, Volume 10 , Number 2 (2002): 117-154. Burhani, Ahmad Najib, "Aksi Bela Islam: Konservatisme dan Fragmentasi Otoritas Keagamaan”, Maarif, Volume 11, Number 2 (2016): 15-29.

Cainkar, A. Louise, Homeland insecurity: The Arab American and Muslim American experience after 9/11. New York: Russsel Sage Foundation, 2011.

Carnerero, Carmen Aguilera and Abdul Halik Azeez, "Islamonausea, not Islamophobia': The Many Faces of Cyber Hate Speech”, Journal of Arab $\mathbb{E}$ Muslim Media Research, Volume 9, Number 1 (2016): 21-40.

Citron, Danielle Keats, Hate Crimes in Cyberspace. Cambridge: Harvard University Press, 2016.

Daniel, Trottier and Fuchs, Christian, Social Media, Politics and the State: Protest, Revolutions, Riots, Crime and Policing in the Age of Facebook, Twitter and Youtube. New York: Routledge, 2015.

Echchaibi, Nabil, "Muslimah Media Watch: Media Activism and Muslim Choreographies of Social Change", Journalism, Volume 14, Number 7 (2013): 852-867.

Erjavec, Karmen and Kovacic, Melita Poler, "You Don't Understand, This is a New War!" Analysis of Hate Speech in News Web Sites' Comments”, Mass Communication and Society, Volume 15, Number 6 (2012): 899-920.

Evolvi, Giulia, "Hate in a Tweet: Exploring Internet-Based Islamophobic Discourses”, Religions, Volume 9, Number 10 (2018): 1-14.

Fakhrizal, Fakhri, "Ahok Izinkan Rumah Makan Buka Selama Ramadan". Retrieved on February 23, 2019 from http://news.okezone.com/ $\mathrm{read} / 2015 / 06 / 17 / 338 / 1166741 /$ ahok-izinkan-rumah-makan-buka-selamaramadan

Fauzi, Ihsan Ali, Bagir, Zainal Abidin, and Kebebasan, Irsyad Rafsadi. Toleransi dan Terorisme; Riset dan Kebijakan Agama di Indonesia. Jakarta: Pusat Studi Agama dan Demokrasi Yayasan Paramadina, 2017.

Gallie, Walter B, "Essentially Contested Concepts", Proceedings of the Aristotelian Society, Volume 56 (1995): 167-198.

Garner, Steve and Selod, Saher, "The Racialization of Muslims: Empirical Studies of Islamophobia", Critical Sociology, Volume 41, Number 1 (2015): 9-19. 
Hebbani, Aparna and Wills, Charise-Rose, "How Muslim Women in Australia Navigate through Media (Mis)Representations of Hijab/Burqa", Australian Journal of Communication, Volume 39, Number 1 (2012): 87-100.

Hebling, Marc. Islamophobia in the West; Measuring and Explaining Individual Attitudes. London: Routledge, 2014.

Hodges, Ernest VE and David G. Perry, "Personal and Interpersonal Antecedents and Consequences of Victimization by Peers", Journal of Personality Social Psychology, Volume 76, Number 4 (1999): 677-685.

Howard, Philip N and Parks, Malcolm R, "Social Media and Political Change: Capacity, Constraint, and Consequence", Journal of Communication, Volume 62, Number 2 (2012): 359-362.

Imhoff, Roland and Julia Recker, "Differentiating Islamophobia: Introducing a New Scale to Measure Islamoprejudice and Secular Islam Critique", Political Psychology, Volume 33, Number 6 (2012): 811-824.

Jaishankar, Karuppannan, "Cyber Hate: Antisocial Networking in the Internet", International Journal of Cyber Criminology, Volume 2, Number 2 (2008): 16-20.

Jaspal, Rusi and Marco Cinnirella, "Media Representations of British Muslims and Hybridised Threats to Identity", Contemporary Islam, Volume 4, Number 3 (2010): 289-310.

Kent, Michael L. "Directions in Social Media for Professional and Scholars", in R.L. Heath (ed), Handbook of Public Realitions. Thousand Oaks: Sage, 2010: 643-656.

Kuncahyo, Wahyu Sabda, "Tolak Larangan Ahok, PPP Gelar Takbir Keliling”. Retrieved on February 25, 2019 from http://nusantara.rmol.co/ $\mathrm{read} / 2016 / 07 / 05 / 252300 /$ Tolak-Larangan-Ahok,-PPP-Gelar-TakbirKeliling=-

Kunst, Jonas R., David L. Sam, and Pal Ulleberg, "Perceived Islamophobia: Scale Development and Validation", International Journal of Intercultural Relations, Volume 37, Number 2 (2013): 225-237.

Lister, Martin, et al. New Media: a Critical Introduction. London: Routledge, 2010. Massaro, Toni M, "Equality and Freedom of Expression: e Hate Speech Dilemma", William E Mary Law Review, Volume 32, Number 2 (1991): 211-265.

Media, Zetro, Habib Rizieq, "Kalau Tuhan beranak bidannya siapa?", Retrieved on December 29, 2018 from ://www.youtube.com/watch?v=H7LdbSDPRg4

Meer, Nasar and Modood, Tariq "Patterns of Prejudice Refutations of Racism in the "Muslim Question", Patterns of Prejudice, Volume 43, Number 3-4 (2009): 335-354. 
Mietzner, Marcus, “Comparing Indonesia's Party Systems of the 1950s and the Post-Soeharto Era: From Centrifugal to Centripetal Inter-party Competition”, Journal of Southeast Asian Studies, Volume 39, Number 3 (2008): 431-453.

Moordiningsih, Islamophobia dan Strategi Mengatasinya. Yogyakarta: Universitas Gadjah Mada, 2004.

Moosavi, Leon, "The Racialization of Muslim Converts in Britain and Their Experiences of Islamophobia”, Critical Sociology, Volume 41, Number 1 (2015): 41-56.

Nadal, Kevin. L., et al., "Subtle and Overt Forms of Islamophobia: Microaggressions toward Muslim Americans”, Journal of Muslim Mental Health, Volume 6, Number 2 (2012) : 16-37.

Ogan, Christine., Lars Willnat, Rosemary Pennington and Manaf Bashir, "The Rise of anti-Muslim prejudice: Media and Islamophobia in Europe and the United State", International Communication Gazette, Volume 76, Number 1 (2014): 27-46.

Perocco, Fabio, "Anti-Migrant Islamophobia in Europe. Social Roots, Mechanisms and Actors", REMHU: Revista Interdisciplinar da Mobilidade Humana, Volume 26, Number 53, (2018): 25-40.

Pettigrew, Thomas F and Roel W. Meertens, "Subtle and blatant prejudice in Western Europe”, European Journal of Social Psychology, Volume 25, Number 1 (1995): 57-75.

Pew Research Center, "U.S. Muslims Concerned About Their Place in Society, but Continue to Believe in the American Dream, " Pew Research Center. Religion and Public Life, 2017. Retrieved on April 23, 2019 at: https://www. pewresearch.org/wp-content/uploads/sites/7/2017/07/U.S.-MUSLIMSFULL-REPORT.pdf

Pohjonen, Matti and Sahana Udupa, "Extreme Speech Online: A Anthropological Critique of Hate Speech Debates", International Journal of Communication, Volume 11 (2017): 1173-1191.

Poole, Elizabeth and Richardson John E. Muslims and the News Media. London: I.B.Tauris, 2014.

Poynting, Scott and Linda Briskman, "Islamophobia in Australia: From Far-Right Deplorables to Respectable Liberals”, Social Sciences, Volume 7, Number 11 (2018): 1-17.

Qodar, Nafiysul, "Polisi tangkap pemilik akun @reza_hardiansyah_7071 yang hina Islam”, 2018, Merdeka.com. Retrieved on February 23, 2019 
from https://www.merdeka.com/peristiwa/polisi-tangkap-pemilik-akunrezahardiansyah7071-yang-hina-islam.html

Said, Edward W. Orientalis. London: Penguin, 2003.

Stack, Liam, "Trump's Executive Order on Immigration: What We Know and What We Don't”, Retrieved on September 29, 2018 from https://www. nytimes.com/2017/01/29/us/trump-refugee-ban-muslim-executive-order. html

Subagyo, P. Ari, "Representasi Frame dalam Latar Belakang Wacana Tajuk tentang Terorisme", Litera, Volume 15, Number 1 (2016): 173-188.

Suler, John, "The Online Disinhibition Effect", Cyberpsychology and Behavior, Volume 7, Number 3 (2004): 321-325.

Syahputra, Iswandi, "Demokrasi Virtual dan Perang Siber di Media Sosial: Perspektif Netizen Indonesia", Jurnal ASPIKOM, Volume 3, Number 3 (2017): 457-475.

Syahputra, Iswandi, "Media Sosial dan Prospek Muslim Kosmopolitan: Konstruksi \& Peran Masyarakat Siber pada Aksi Bela Islam”, Jurnal Komunikasi Islam, Volume 8, Number 1 (2018): 19-40.

Trust, Runnymede, Islamophobia: A Challenge for Us All, 1997, Retrieved on April 23, 2019 at: https://www.runnymedetrust.org/companies/17/74/ Islamophobia-A-Challenge-for-Us-All.html.

Vidgen, Bertie and Yasseri, Taha"Detecting Weak and Strong Islamophobic Hate Speech on Social Media", retrieved on September 27, 2018 at https:// arxiv.org/abs/1812.10400

Wildan, Muhammad, "Aksi Damai 411-212, Kesalehan Populer, dan Identitas Muslim Perkotaan Indonesia", Maarif, Volume 11, Number 2 (2016): 188-202.

Wood, Andrew F and Matthew J. Smith, Online Communication: Linking, Technology, Identity, and Culture. New York and London: Routledge, 2017.

Woodlock, Rachel, "Identity and Islamophobia: An Australian Investigation", in Douglas Pratt and Rachel Woodlock (ed). Fear of Muslims?: International Perspectives on Islamophobia. Switzerland: Springer, 2016: 131-151.

Woodward, Mark and Nurish, Amanah, "Quo Vadis FPI dalam Aksi Bela Islam", Maarif, Volume 11, Number 2 (2016): 105-122.

Yuanita, "Ahok Larang Pemotongan Hewan Kurban di Sekolah". Retrieved on February 24, 2019 from http://metro.sindonews.com/read/1042040/171/ ahok-larang-pemotongan-hewan-kurban-di-sekolah-1441692072 